TRENDS IN HYDROZOAN BIOLOGY - IV. C.E. MILLS, F. BOERO, A. MIGOTTO and J.M. GILI (eds.)

\title{
Deep-water Hydromedusae from the Lacaze-Duthiers submarine canyon (Banyuls, northwestern Mediterranean) and description of two new genera, Guillea and Parateclaia*
}

\author{
J. BOUILLON ${ }^{1}$, F. PAGÈS ${ }^{2}$, J.-M. GILI², A. PALANQUES ${ }^{2}$, P. PUIG ${ }^{2}$ and S. HEUSSNER ${ }^{3}$ \\ ${ }^{1}$ Laboratoire de Biologie Marine, Faculté des Sciences, Université Libre de Bruxelles, Av. F. Roosevelt 50, \\ 1050 Bruxelles, Belgium. \\ ${ }^{2}$ Institut de Ciències del Mar (CSIC), Plaça del Mar s/n, 08039 Barcelona, Catalonia, Spain. \\ ${ }^{3}$ Centre de Formation et de Recherche sur l'Environment Marin, CNRS UMR 5110, Université de Perpignan, \\ 52 Avenue de Villeneuve, 66860 Perpignan Cedex, France.
}

\begin{abstract}
SUMMARY: Several species of hydromedusae are reported from material collected by sediment traps placed in the LacazeDuthiers submarine canyon, off Banyuls (north-western Mediterranean). Two new taxa Guillea canyonincolae gen. nov. et sp. nov. and Parateclaia euromarge fam. nov., gen. nov. et sp. nov., are described. The existence of highly-specific hydromedusa populations in other Mediterranean canyons which appear to be related via geological history, topography, hydrographic and ecological features peculiar to each canyon, is discussed in relation to these new records.
\end{abstract}

Key words: Hydromedusae, submarine canyons, western Mediterranean, swimmers, deep-sea fauna, biodiversity, Guillea canyonincolae, Parateclaia euromarge.

\section{INTRODUCTION}

Interactions between the fluctuating continental runoff flows over the shelf and slope areas with abrupt topographies, together with local circulation and mass balance, give nearshore submarine canyons a key role in some coastal ecosystems, enhancing species richness and biological productivity (Hickey, 1995). The channeling of organic matter from the shelf to deep water through submarine canyons gives rise to high biomass levels and production rates in the plankton and benthos in such

\footnotetext{
*Received August 24, 2000. Accepted September 30, 2000.
}

canyons (Greene et al., 1992; Vetter, 1994, 1995; Vetter and Dayton, 1998) resulting in biological communities in submarine canyons that are more productive and diverse than was thought only a short time ago (Gage and Tyler, 1992; Gage et al., 1995).

In the north-western Mediterranean, submarine canyons occupy nearly $50 \%$ of the total continental slope. Recent investigations carried out in some of them have revealed a deep-water fauna composed mainly of meroplanktonic hydromedusae (see Gili et al. 1998, 1999, 2000). Spatio-temporal trends in the organic (carbon and biogenic silica) content of vertical fluxes of particulate matter have yielded a good match with the number of individuals and 
species of hydromedusae collected in these canyons (Gili et al., 2000). These observations led us to postulate the presence of unique plankton populations in these canyons, which are probably supported by the flux and storage of organic material coming from the continental shelf.

Previous studies carried out in three canyons (Fig. 1), Foix (near Barcelona), Lacaze-Duthiers (near Banyuls) and Planier (near Marseille) have shown that the specific composition and abundance of the medusa populations appear to be different between canyons (Gili et al. 1998, 1999, 2000). These studies covered an entire year in the Foix canyon while in other canyons, temporal trends had to be inferred from less sampling. The present study represents results derived from a second survey in the Lacaze-Duthiers canyon, carried out from December 1995 to January 1997. During that period, sediment traps collected several species of hydromedusae including the two new ones described here. Their occurrence is analysed, taking into account the previously proposed hypotheses (Gili et al., 1998,
1999, 2000), suggesting the existence of specific hydromedusa populations in each canyon investigated; such specificity seems closely related to the geological history, topography, and both hydrographic and ecological features of each of the studied canyons.

\section{MATERIAL AND METHODS}

A mooring line equipped with sequential sediment traps was deployed at a single station in the Lacaze-Duthiers canyon. One sediment trap was located at $1000 \mathrm{~m}$ depth, $30 \mathrm{mab}$ (metres above the bottom) and another in intermediate waters $500 \mathrm{mab}$ during a full-year sampling period (December 1995January 1997). The sediment traps were Technicap model PPS3, which incorporates a carousel with 12 rotary collectors (Heussner et al., 1990). The sample collecting interval was set at 15 or 16 days, depending on the month. Before trap deployments, the sample tubes were rinsed and filled with a neutralized

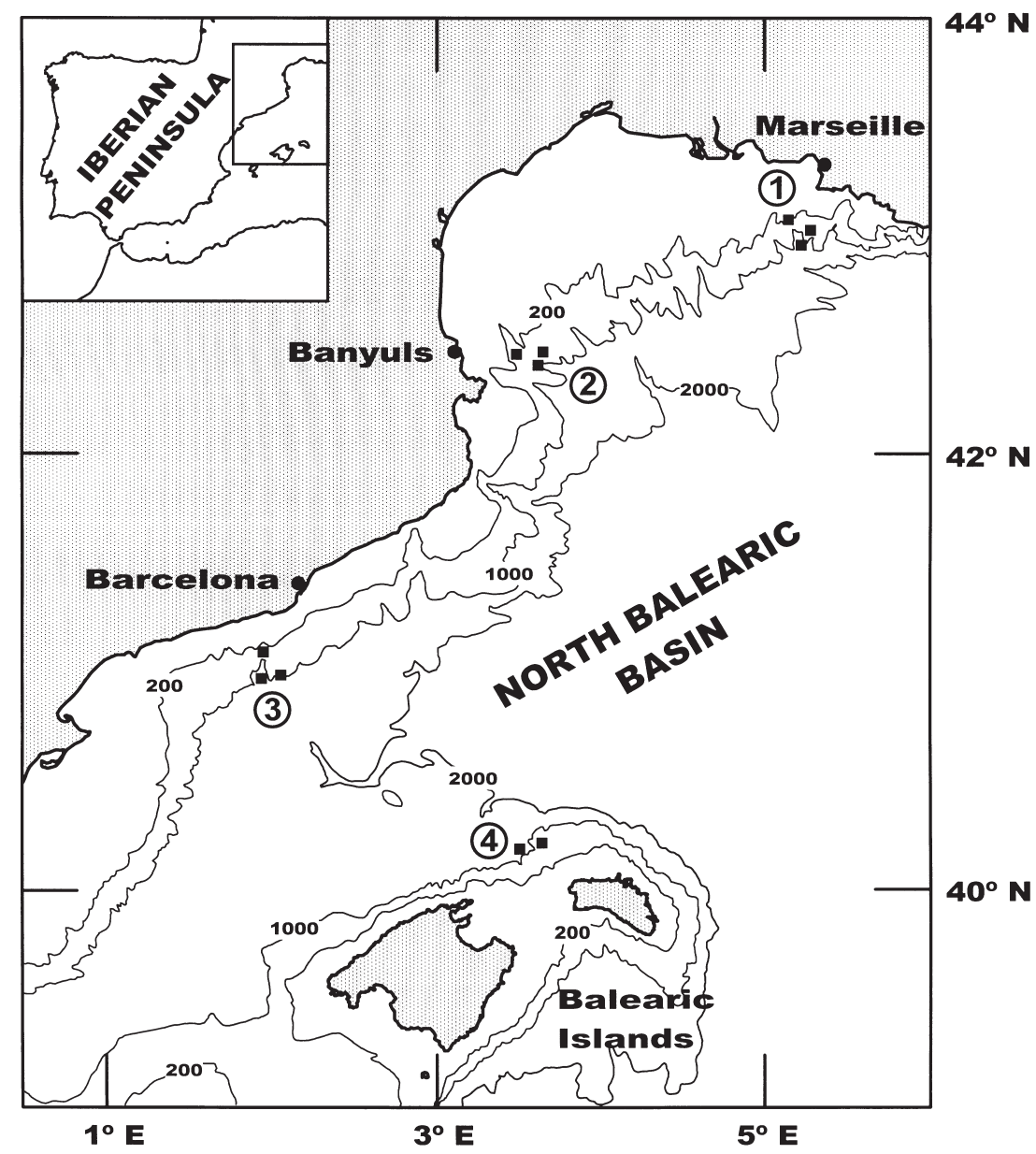

FIG. 1. - Map of the study-area, showing the location of the mooring sites (black squares) during the EUROMARGE-NB experiments. Site 1: Planier canyon; site 2: Lacaze-Duthiers canyon; site 3: Foix canyon; site 4: Balearic slope. 
$5 \%$ formaldehyde solution in filtered seawater to prevent degradation of organic matter between collection and the time that the traps were taken up. The samples were processed in the laboratory and swimmers were removed by hand-picking under a dissecting microscope. Gelatinous swimmers had been preserved in excellent condition, which facilitated taxonomic investigations of the hydromedusae.

\section{RESULTS}

\section{Material collected and species descriptions}

\author{
ANTHOMEDUSAE \\ FILIFERA \\ Family PANDEIDAE Haeckel, 1879
}

Leuckartiara brownei Larson and Harbison, 1990 (Fig. 2)

Material examined: 1 specimen, $7.0 \mathrm{~mm}$ high, 15-31 October 1996, $500 \mathrm{~m}$ depth.

This is the first record of this species in the Mediterranean. It was previously recorded only in the Southern Ocean, in surface waters of the Ross Sea (Larson and Harbison, 1990) and in the Weddell Sea where several specimens were collected from the surface down to the 720-450 m depth range (Pagès and Schnack-Schiel 1996; Pagès unpublished data).

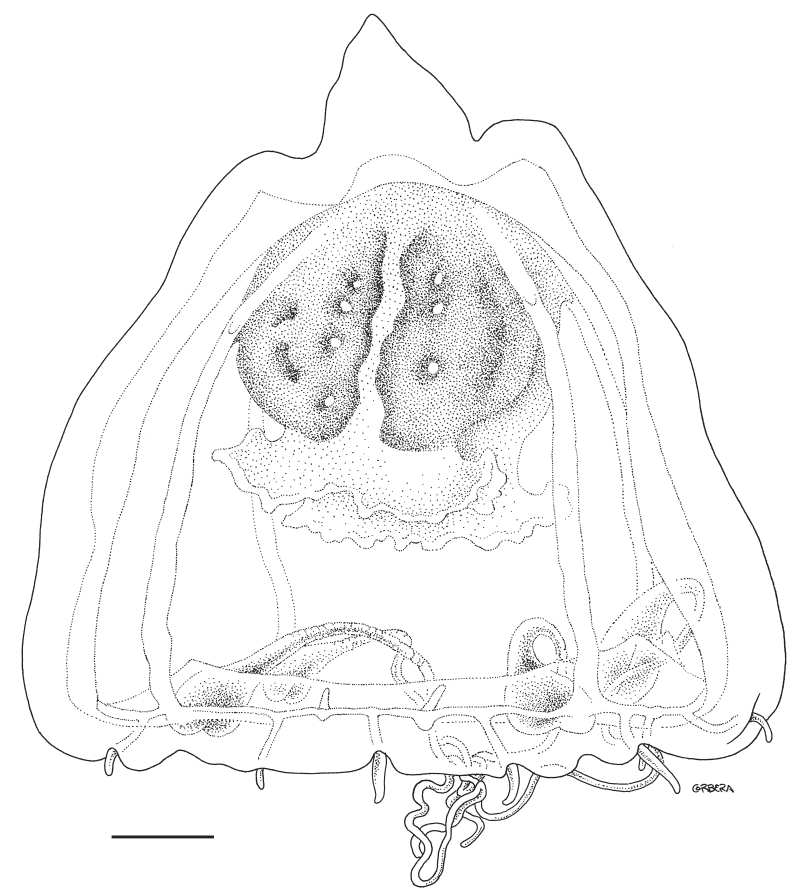

FIG. 2. - Leuckartiara brownei. Scale: $1 \mathrm{~mm}$.
CAPITATA

Family EuPHYSIDAE Haeckel, 1879

Euphysa aurata Forbes, 1848

Material examined: 1 specimen, $3.3 \mathrm{~mm}$ high, 16 March-1 April 1996, 500 m depth.

Family ZANCLEIDAE Russell, 1953

\section{Zanclea sp.}

Material examined: 1 specimen, colour deep red, $3.6 \mathrm{~mm}$ high, 1-15 May 1996, $500 \mathrm{~m}$ depth.

\section{LEPTOMEDUSAE}

Family LAODICEIDAE Agassiz, 1862

Diagnosis: Leptomedusae with marginal cordyli with or without cnidocysts; with 4,8 , or more simple or branched radial canals; gonads on radial canals, on radial canals and lobes of manubrium or in manubrial pouches; marginal tentacles hollow; with or without marginal cirri; with or without adaxial ocelli; without statocysts.

\section{Guillea gen. nov.}

Etymology: This genus is dedicated to Prof. Alain Guille for his outstanding activities as Director of the Observatoire Océanologique de Banyuls (Laboratoire Arago) and for his relevant contribution to the knowledge of the Mediterranean marine fauna. Prof. Alain Guille is one of the founders of the Laboratoire European des Sciences de la Mer (LEA), within whose framework this and previous works related to medusae in submarine canyons have been carried out.

Diagnosis: Laodiceidae with club-shaped cordyli; with marginal cirri; with adaxial ocelli; with 4 simple radial canals; manubrium with perradial pouches, with gonads developing in numerous dorso-lateral lamellar folds (gonadal diverticulae) extending from the proximal part of manubrium into the manubrial pouches and out onto the proximal portions of the radial canals.

Remarks: This new genus has the basic characters of the family Laodiceidae. It is close to the genus Laodicea by virtue of its club-shaped cordyli, marginal cirri and ocelli; it also shows affinities with the genus Ptychogena by the presence of manubrial pouches and gonadial diverticulae. However, the genus Ptychogena has been classically defined as deprived of cirri and ocelli; therefore the new genus Guillea is here proposed. This new genus appears to have characters intermediate between the genera Laodicea and Ptychogena. 


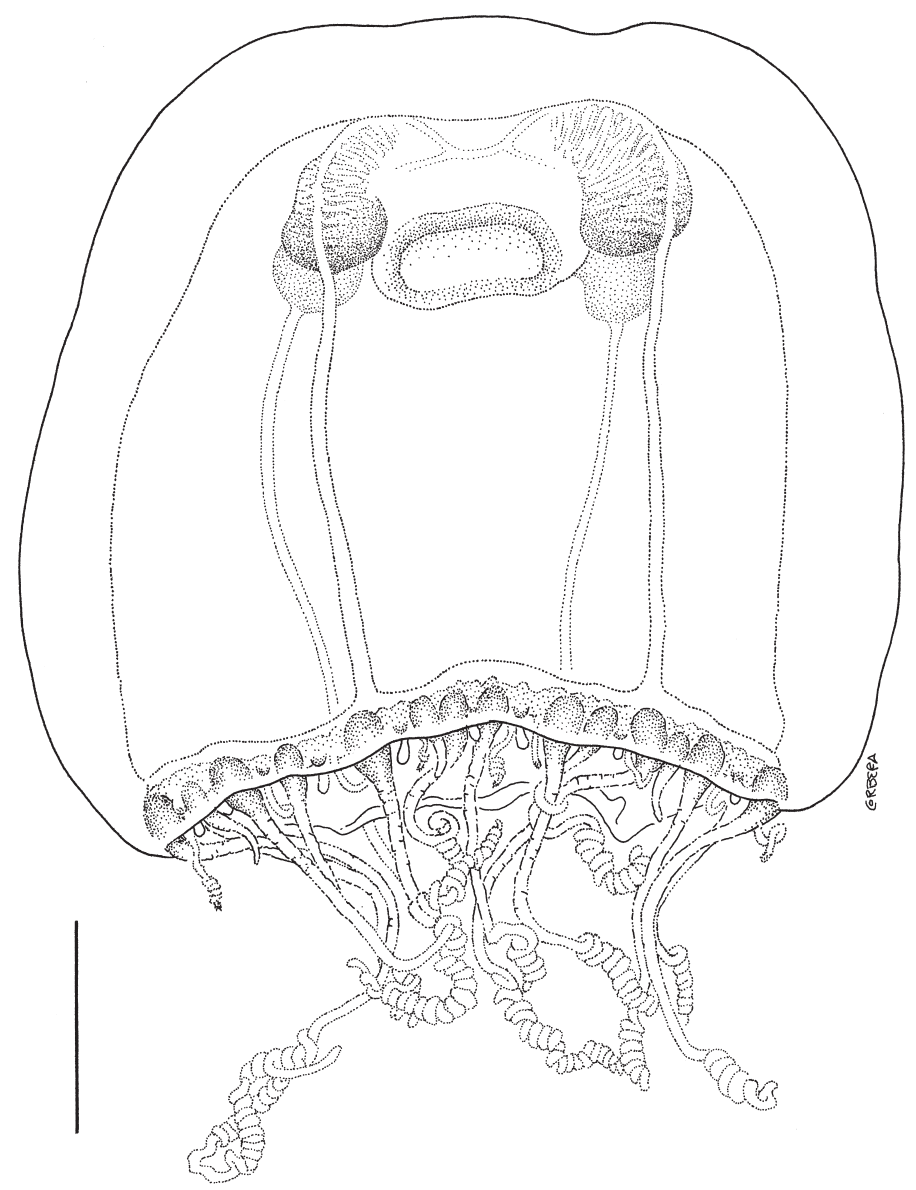

FIG. 3. - Guillea canyonincolae. Scale: $1 \mathrm{~mm}$

a

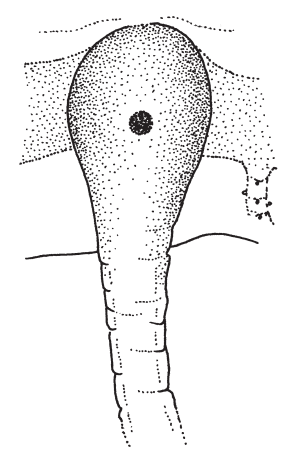

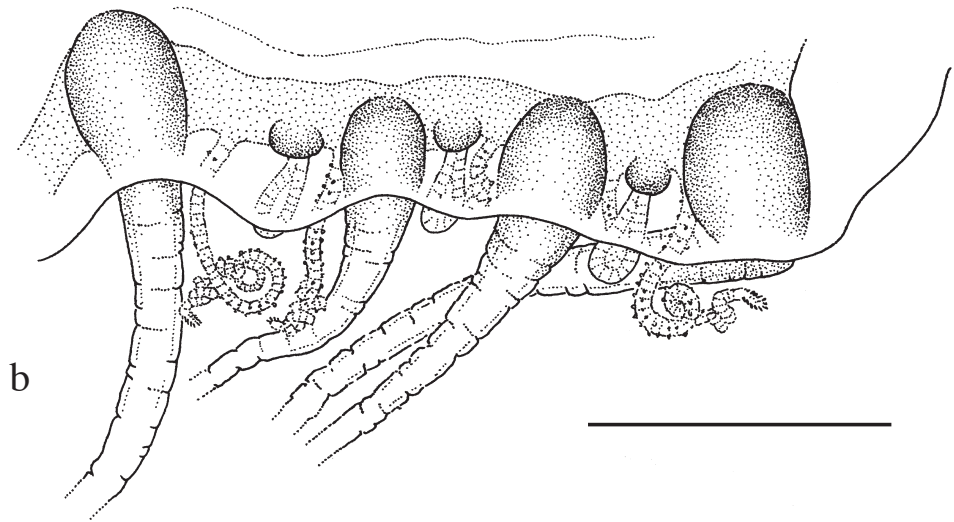

FIG. 4. - Guillea canyonincolae, detail of the umbrella margin; (a) adaxial view of the tentacle, showing ocellus; (b) abaxial view, showing club-shaped cordyli and spiral cirri. Scale: $0.5 \mathrm{~mm}$.

Guillea canyonincolae sp. nov.

(Figs. 3 and 4)

Type locality: Lacaze-Duthiers canyon, off Banyuls (France), northwestern Mediterranean.

Material examined: one specimen collected at $500 \mathrm{~m}$ depth on 1-16 March 1996 and deposited at the Institut de Ciències del Mar, Barcelona, Spain.

Etymology: canyonincolae, inhabitant of canyons.
Description: Umbrella higher than a hemisphere, dome-shaped, $4.5 \mathrm{~mm}$ wide, $4.0 \mathrm{~mm}$ high; with vertical walls and flatly rounded apex, mesoglea uniformly thick; velum narrow; manubrium quadrangular, short, with four perradial gastric pouches; mouth large, almost circular, without distinct lips but with swollen margin, faintly folded; four simple narrow radial canals not meeting exactly in the center of 
manubrial roof; circular canal narrow; four perradial gonads, differentiating into numerous dorso-lateral lamellar folds (gonadal diverticulae), extending from proximal part of manubrium into the gastric pouches to proximal parts of the radial canals; up to 24 marginal tentacles with coiled extremities; marginal bulbs broad, rounded; one club-shaped cordylus without cnidocysts and one to two spiral cirri between successive tentacles; one ocellus on the adaxial side of each marginal bulb.

Diagnosis: Umbrella higher than a hemisphere, dome-shaped, $4.5 \mathrm{~mm}$ wide, $4.0 \mathrm{~mm}$ high; with rounded apex, mesoglea uniformly thick; manubrium quadrangular, short, with four perradial pouches; mouth large, without distinct lips; four simple narrow radial canals; circular canal narrow; 4 perradial gonads differentiating into dorso-lateral lamellar folds (gonadal diverticulae) from proximal part of manubrium into the gastric pouches to the proximal parts of the radial canals; up to 24 marginal tentacles; marginal bulbs broad, rounded, each with one adaxial ocellus; one cordylus and one to two spiral cirri between successive tentacles.

Family Mitrocomidae Torrey, 1909

Foersteria antoniae Gili, Bouillon, Pagès, Palanques, Puig and Heussner 1998

Material examined: All specimens were collected at $500 \mathrm{~m}$ depth; 2 specimens, 16 February-1 March 1996; 2 specimens, 1-16 March 1996; 3 specimens, 16 March-1 April 1996; 3 specimens, 1-16 April
1996; 3 specimens, 16 April-1 May 1996; 3 specimens, 1-16 May 1996; 2 specimens, 16 July-1 August 1996; 3 specimens, 1 August1 September 1996; 3 specimens, 5-6 mm wide, 1-16 September 1996. Size: 4.1-6.2 $\mathrm{mm}$ wide.

\section{Family TeCLAIIDAE fam. nov.}

Diagnosis: Leptomedusae with 4 simple radial canals; with hollow tentacles; with 4 simple lips; with gonads elongated forming linear sacs on radial canals, separated from manubrium; with one to three cordyliform structures between successive tentacles; without ocelli; without cirri; with or without open statocysts.

Parateclaia gen. nov.

Diagnosis: Teclaiidae with open statocysts.

\section{Parateclaia euromarge sp. nov.}

(Figs. 5 and 6)

Type locality: Lacaze-Duthiers canyon, off Banyuls (France), northwestern Mediterranean.

Material examined: 3 specimens, 16 July 1996; 2 specimens, 1-16 August 1996; 2 specimens, 1-16 September 1996. All specimens were collected at $1000 \mathrm{~m}$ depth. Holotype and paratypes deposited at the Institut de Ciències del Mar, Barcelona, Spain.

Etymology: euromarge in acknowledgement of the European Community research program EUROMARGE which made possible the study of the medusan fauna in submarine canyons.

Description: Umbrella to $6.0 \mathrm{~mm}$ wide, $4.5 \mathrm{~mm}$ high; somewhat flatter than a hemisphere; mesoglea

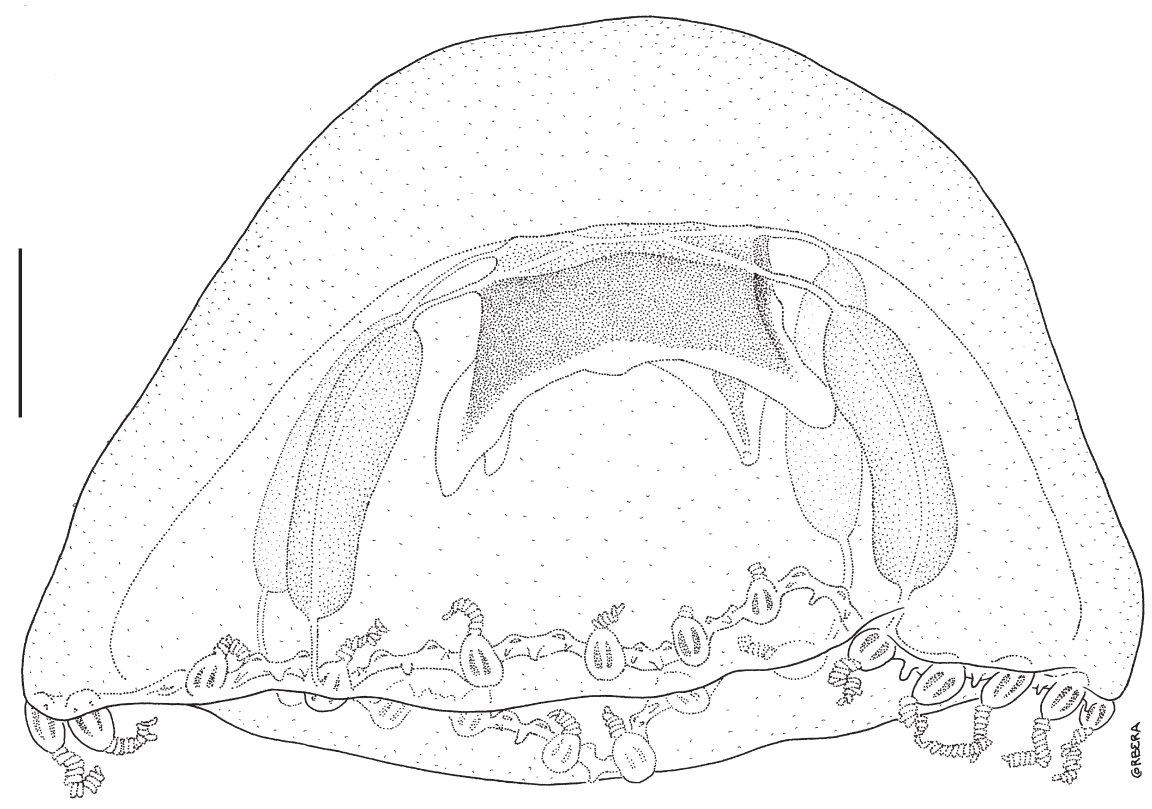

FIG. 5. - Parateclaia euromarge. Scale: $1 \mathrm{~mm}$ 
fairly thick at the apex, thinning towards umbrella margin; exumbrella sprinkled with cnidocysts; velum narrow; manubrium short, square, with large base, about $1 / 4$ of subumbrella cavity height and 1/3 of subumbrella cavity width, without gastric peduncle, colour light brown; mouth with 4 simple groove-like lips, white in colour; as long as manubrium height; with 4 simple radial canals not meeting in the centre of the manubrial roof, circular canal narrow; up to 24 hollow marginal tentacles; with elongated conical marginal bulbs each with two large brown bands; up to three cordyliform conical structures, each with central brown pigment spots and terminal cnidocysts; one to two open statocysts between successive marginal tentacles; gonads elongated, cylindrical, extending along the middle $2 / 3$ of the radial canals and leaving both ends free.

Remarks: Teclaia recincolae Gili, Bouillon, Pagès, Palanques and Puig 1999 was tentatively referred to the Laodiceidae by Gili et al., (1999). The discovery of this new species, which is nearly completely identical to $T$. recincolae except for the presence of open statocysts, questions the family position of this genus which is taken out from the Laodiceidae. Only two previously described families of Leptomedusae have open statocysts, the Mitrocomidae and the Tiaropsidae (Bouillon, 1985). The latter exhibits very special compound sense organs formed by the association of ocelli and an open statocyst which excludes it from the present discussion. The Mitrocomidae constitutes a uniform family mainly characterised by the possession of open statocysts and without cordyli. The inclusion of species without statocysts and with cordyliform structures would greatly disturb the definition of this family. We prefer to create a new family for these two very unusual deep-water species. Teclaia recincolae has been found in the Foix canyon, Catalán Sea at 1210-1180 m depth (see Table 1). None of the specimens observed (81) had open statocysts. All the specimens of Parateclaia euromarge have been found in the Lacaze-Duthiers canyon off Banyuls at $500 \mathrm{~m}$ depth and had open statocysts. As stated above these two genera are almost indistinguishable except for the presence/absence of sense organs. They presumably differentiated from a common ancestor, having been isolated by geological events in the above-mentioned canyons. Whether the original species did or did not have open statocysts is an insoluble question, but open statocysts are a character found in many deep-water medusae (see Gili et al., 1998).

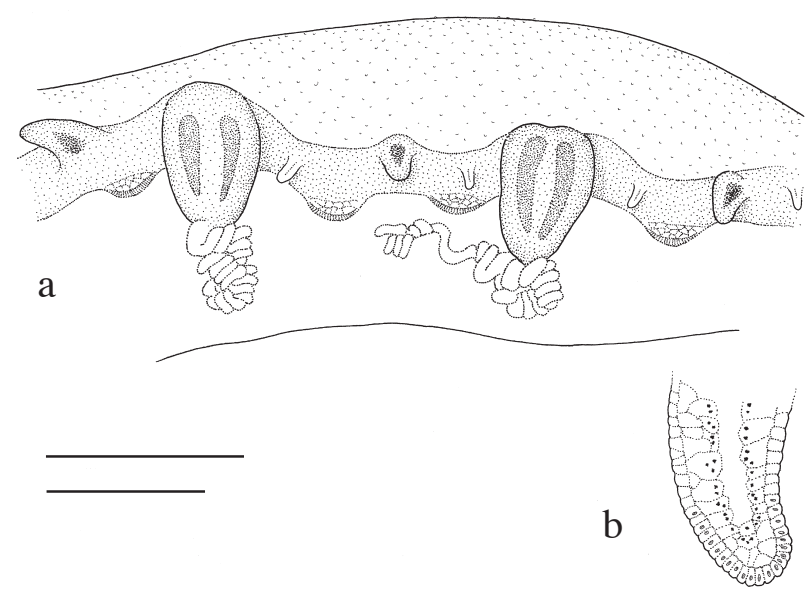

FIG. 6. - Parateclaia euromarge, detail of the umbrella margin: (a) abaxial view showing the elongated conical marginal bulbs, each with two large brown bands, the cordyliform conical structures, and the open statocysts between successive marginal tentacles. Scale: $0.5 \mathrm{~mm}$; (b) microscopic view of the cordyliform structures with terminal cnidocysts. Scale: $0.05 \mathrm{~mm}$.

\section{NARCOMEDUSAE}

Family CunINIDAE Bigelow, 1913

Cunina simplex Gili, Bouillon, Pagès, Palanques, Puig and Heussner, 1998

Material examined: 1 specimen, 1 August-1 September 1996; 1 specimen, 1-16 September 1996; 1 specimen, 1-16 October 1996. Size: $3.7-4.0 \mathrm{~mm}$ wide.

\section{Solmissus albescens (Gegenbaur, 1857)}

Material examined: 3 specimens, 1-16 January 1996; 1 specimen, 116 February 1996; 1 specimen, 16 April-1 May 1996; 1 specimen, 1 16 May 1996; 1 specimen, 1-16 December 1996; all these specimens were collected at $500 \mathrm{~m}$ depth. In addition one specimen collected at $1000 \mathrm{~m}$ depth on 1-15 December 1995. Size: $2.1-2.8 \mathrm{~cm}$ wide.

\section{TRACHYMEDUSAE}

Family PTYCHOGASTRIIDAE Mayer, 1910

Ptychogastria asteroides (Haeckel, 1879)

Material examined: 1 specimen, 16 March-1 April 1996; 1 specimen, 1-16 April 1996; 2 specimens, 16 April-1 May 1996; 4 specimens, 16 May-1 June 1996; 3 specimens, 1-16 June 1996; all these specimens were collected at $500 \mathrm{~m}$ depth. In addition one specimen collected at $1000 \mathrm{~m}$ depth on 1-16 October 1996. Size: 1-4 mm high.

Family Rhopalonematidae Russell, 1953

Homoeonema platygonon Browne, 1903

Material examined: 1 specimen, 1.4 mm high, 15-31 October 1996, $500 \mathrm{~m}$ depth.

\section{Persa incolorata McCrady, 1859}

Material examined: 2 specimens, 1.8-2.1 mm high, 1-16 June 1996, $500 \mathrm{~m}$ depth. 
TABLE 1. - Species collected in the three submarine canyons investigated in the western Mediterranean. New species described are in bold. The species collected at stations located outside the canyons and cited in previous studies (Gili et al., 1998, 1999, 2000) are also listed.

\begin{tabular}{|c|c|c|c|c|}
\hline & Foix & Lacaze-Duthiers & Planier & $\begin{array}{l}\text { Stations } \\
\text { outside of } \\
\text { canyons }\end{array}$ \\
\hline Foersteria araiae Gili, Bouillon, Pagès, Palanques and Puig, 1999 & • & & & \\
\hline Teclaia recincolae Gili, Bouillon, Pagès, Palanques and Puig, 1999 & $\bullet$ & & & \\
\hline Barcino foixensis Gili, Bouillon, Pagès, Palanques and Puig, 1999 & $\bullet$ & & & \\
\hline Solmissus albescens (Gegenbaur, 1857) & $\bullet$ & $\bullet$ & $\bullet$ & \\
\hline Ptychogastria asteroides (Haeckel, 1879) & - & $\bullet$ & • & \\
\hline Homoeonema platygonon Browne, 1903 & $\bullet$ & $\bullet$ & - & \\
\hline Calycopsis simplex Kramp and Damas, 1925 & & $\bullet$ & & \\
\hline Euphysa aurata Forbes, 1848 & & $\bullet$ & & \\
\hline Cunina simplex Gili, Bouillon, Pagès, Palanques, Puig and Heussner, 1998 & & • & & \\
\hline Solmaris flavescens (Kölliker, 1853) & & • & & \\
\hline Leuckartiara brownei Larson and Harbison, 1990 & & $\bullet$ & & \\
\hline Guillea canyonincolae gen. nov., sp. nov. & & • & & \\
\hline Parateclaia euromarge gen. nov., sp. nov & & $\bullet$ & & \\
\hline Persa incolorata McCrady, 1859 & & - & $\bullet$ & \\
\hline Zanclea spp. & & & - & \\
\hline Haliscera racovitzae (Maas,1906) & & & $\bullet$ & \\
\hline Arctapodema australis (Vanhöffen, 1902) & & & $\bullet$ & \\
\hline Sminthea eurygaster Gegenbaur, 1857 & & & & - \\
\hline Amphinema rubra (Kramp, 1957) & & & & • \\
\hline Modeeria rotunda (Quoy and Gaimard,1827) & & & & $\bullet$ \\
\hline Cunina globosa Eschscholtz, 1829 & & & & $\bullet$ \\
\hline Haliscera bigelowi Kramp, 1947 & & & & $\bullet$ \\
\hline
\end{tabular}

\section{GENERAL REMARKS}

Recent investigations carried out in four western Mediterranean submarine canyons have shown that the specific composition and abundance of the hydromedusa populations differ between each canyon (see Table 1). These differences may be related to environmental factors which are summarized as follows:

1) The seasonal fluxes observed inside submarine canyons possibly enhance species abundance and the geomorphological structure of each canyon appears to have a great influence on its faunal composition. For instance, the narrowest canyons (such as Foix), having less communication with the open sea, appear to favour species isolation and so seemingly have induced greater speciation over evolutionary times.

2) Flux of biogenic components varies according to location and period of the year and it increases downstream (from Planier to Foix canyons), following the Northern Current. The number and abundance of endemic species also appears to increases from Planier to Foix canyons.

3) Seasonal distribution of the most abundant canyon hydromedusae, all of which are meroplanktonic, reflects the probable existence of a polyp or other resting stages, and a life-cycle adapted to the environmental fluctuations inside the canyons.
The highest number of species and individuals have been collected from March to mid-June in the traps located nearest the sea floor. However, the global number of medusae in Mediterranean canyons appears to remain quite constant, because some specimens have also been collected during summer in the intermediate-depth traps (Fig. 7). Foersteria antoniae, a species only reported from the Lacaze-Duthiers and Planier canyons (Gili et al. 1998) was present in the bottom trap during spring and early summer, while Parateclaia euromarge was present only during summer in the intermediatedepth traps of Lacaze-Duthiers canyon. The medusae collected during autumn and winter were common species like Solmissus albescens and Ptychogastria asteroides that have been recorded in all the Mediterranean canyons investigated (Gili et al. 1998, 1999, 2000).

In order to study relationships between environmental factors and species occurrence, temporal evolution of total mass fluxes inside the LacazeDuthiers canyon during 1996 was studied (Heussner unpublished data) (Fig. 7). The total mass fluxes (Fig. 7a) and the opal (biogenic silica) percentage (Fig. 7b) (derived from biological activity from the surface waters on the shelf) are higher in the spring when the number of both species and individuals of hydromedusae increased in the trap samples. The spring total flux peak (potential food supply to the 

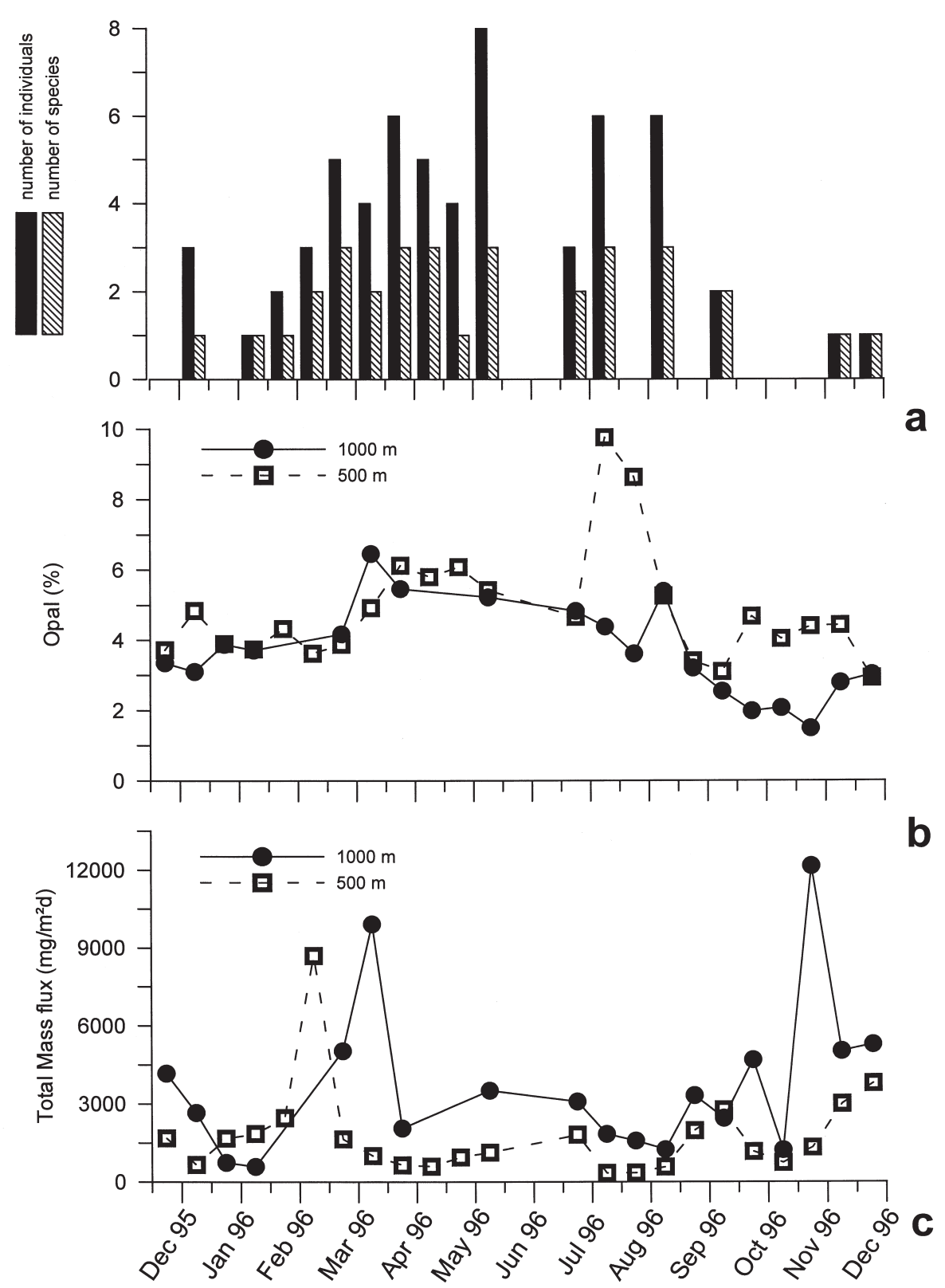

FIG. 7. - Lacaze-Duthiers canyon, 1996: (a) temporal evolution of both the number of individuals and the species of hydromedusae collected during the year; (b) time series of biogenic opal contents; (c) total mass fluxes of settling particulate matter traped 30 mab and 500 mab at the Lacaze-Duthiers canyon on $1000 \mathrm{~m}$ bottom depth.

canyon bed) appears to serve as a threshold episode which triggers medusa population growth. After the spring, medusan populations remain quite constant until early autumn, when both medusa abundance and opal flux decrease. The rather small increase of fluxes during the summer at the intermediate level coincides with the occurrence of Parateclaia euromarge in the traps. These general trends agree with previous observations in the Foix canyon (Gili et al. 2000), where the higher number of individuals and species appears after a peak of biogenic opal caused by the spring discharge of rivers. The observations at the Lacaze-Duthiers canyon seem thus to support the previously mentioned hypotheses concerning environmental control of the biodiversity of medusae inhabiting canyons

In general, the biological and environmental features of the submarine canyons in the north-western Mediterranean lead to the postulation that these habitats shelter a high and perhaps novel faunal diversity, known so far mostly by new species of hydromedusae. The endemic hydromedusan species of the Planier, Lacaze-Duthiers, and Foix canyons are closely related (see Table 1). For instance, Foersteria antoniae occurs 
in low numbers in two canyons, Planier (with very few individuals) and Lacaze-Duthiers canyon, which could mean that both canyons are and/or were connected by currents. Both of those canyons are quite isolated from the southernmost canyon (Foix) where $F$. araiae is the endemic dominant species. More investigations in additional, and still-unstudied canyons located between Foix and Lacaze-Duthiers (near Blanes and Palamós) are needed to define possible biogeographical borders and whether their existence could be related with environmental constraints. The isolation of species could be related to the hypothesis mentioned in previous papers that this fauna appears to be characterised mostly by species that develop their entire life-cycle inside a canyon. These life-cycles seem to be governed by external factors such as transport of organic debris to the sea floor (related to river inputs, storms, etc.), interaction and circulation of water masses along with the canyon's topography, and biological production throughout the water column. These observations have led us to consider submarine canyons as key habitats for the understanding of biodiversity in the shelf and slope zones.

\section{ACKNOWLEDGEMENTS}

This work was supported by the European Community research program EUROMARGE-NB (contract MAS2-CT93-0053) and it has been finished with assistance from the LEA (Associated Marine Laboratory) "Marine Sciences". We are greatly indebted to "Medusa" Mills for useful comments on the manuscript, Mr. Jordi Corbera for the illustrations and Mrs Nicole Delsaut for the sorting of organisms from the trap samples. J.B. gratefully acknowledges the support of the "Fondation Universitaire David and Alice Van Buuren".

\section{REFERENCES}

Bouillon, J. - 1985. Essai de classification des HydropolypesHydroméduses (Hydrozoa-Cnidaria). Indo-Malayan Zool., 2: 29-243.

Gage, J.D. and P.A. Tyler. - 1992. Deep-Sea biology. A natural history of organisms at the deep-sea floor. Cambridge University press, New York.

Gage, J.D., P.A. Lamont and P.A. Tyler. - 1995. Deep-sea macrobenthic communities at contrasting sites off Portugal, preliminary results: introduction and diversity comparisons. Int. Rev. ges. Hydrobiol., 80: 235-250.

Gili, J.-M., J. Bouillon, F. Pagès, A. Palanques and P. Puig. - 1999. Submarine canyons as habitat of singular plankton populations: three new deep-sea hydromedusae in the western Mediterranean. Zool. J. Linn. Soc., 125: 313-329.

Gili, J.-M., J. Bouillon, F. Pagès, A. Palanques, P. Puig and S. Heussner. - 1998. Origin and biogeography of deep water Mediterranean Hydromedusae including the description of two new species collected in submarine canyons of Northwestern Mediterranean. Sci. Mar., 62(1-2): 113-134.

Gili, J.-M., F. Pagès, J. Bouillon, A. Palanques, P. Puig, S. Heussner, A. Calafat, M. Canals and A. Monaco. - 2000. A multidisciplinary approach to the understanding of hydromedusan populations inhabiting Mediterranean submarine canyons. DeepSea Res. I, 47: 1513-1533

Greene, C.H., P.H. Wiebe, J. Burczynskli and M.J. Youngbluth. 1992. Acoustic detection of high-density krill demersal layers in the submarine canyons off Georges Bank. Science, 241: 359361 .

Heussner, S., C. Ratti and J. Carnonne. - 1990. The PP3 timeseries sediment trap and the trap sampling processing techniques used during ECOMARGE experiment. Cont. Shelf Res., 10: 943-958.

Hickey, B.M. - 1995. Coastal submarine canyons. In: P. Müller, and D. Henderson (eds.), Topographic effects in the ocean. SOEST Special publications, pp. 95-110. University of Hawaii, Manoa.

Larson, R.J. and G.R. Harbison. - 1990. Medusae from McMurdo Sound, Ross Sea including the descriptions of two new species, Leuckartiara brownei and Benthocodon hyalinus. Polar Biol., 11: 19-25.

Pagès, F. and S.B. Schnack-Schiel. - 1996. Distribution patterns of the mesozooplankton, principally siphonophores and medusae, in the vicinity of the Antarctic Slope Front (eastern Weddell Sea). J. Mar. Syst., 9: 231-248.

Vetter, E.W. - 1994. Hotspots of benthic production. Nature, 372: 47.

Vetter, E.W. - 1995. Detritus-based patches of high secondary production in the nearshore benthos. Mar. Ecol. Prog. Ser., 120: 251-262.

Vetter, E.W. and P.K. Dayton. - 1998. Macrofaunal communities within and adjacent to a detritus-rich submarine canyon system. Deep-Sea Res. I, 11, 25-54. 